\title{
RELIGIOSIDAD FEMENINA Y LA VIDA COTIDIANA del convento de Santa Clara de Santafé, SIGLOS XVII Y XVIII. \\ Una mirada detrás del velo de Johanna de San Esteban
}

\author{
María Constanza Toquica Clavijo \\ Historiadora, directora de la iglesia Museo Santa Clara \\ mc.toquica@lycos.com
}

Resumen

- STE ARTíCUlO ABORDA LA RELIGIOSIDAD FEMENINA Y LA VIDA COTIDIANA DEL CON[ vento de Santa Clara de Santafé de Bogotá durante la Colonia. Pretende establecer una mirada más cercana a la vida del convento, evadiendo la mediación que el "deber ser" de la documentación normativa impone, impidiendo ver lo que realmente sucedía. Los datos sobre la vida y personalidad de Johanna de San Esteban y de otras protagonistas de la historia del convento ayudan a penetrar en la vida del mismo, a captar las dificultades para percibir el aliento de lo vivido desde la íntima experiencia religiosa femenina, y a realzar la importancia del estudio sobre vida cotidiana, para allegar otras miradas sobre el pasado.

\begin{abstract}
T HIS ARTICLE APPROACHES FEMININE RELIGIOSITY AND DAILY LIFE AT THE SANTA Clare convent in Santafé de Bogota during the Colonial period. It aims to offer a closer view of what happened behind it walls, with less mediation of the "it must be" that standardized documentation allows. Information about the life and personality of Johanna de San Esteban and other protagonists of the convent's life help to penetrate convent's life, to capture the difficulties to approache the breath of lived experience forn the intimate religious experience of feminine religiosity, and to highlight the relevance of daily life studies to reach other views of the past.
\end{abstract}

Revista Colombiana de Antropología

Volumen 37, enero-diciembre 200I, pp. I52-I86 


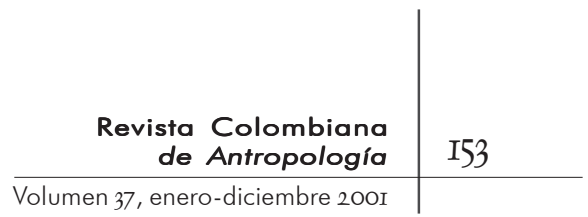

\begin{abstract}
Lo cotidiano representa ciertamente aquella parte del espacio y del tiempo en el que se le ha permitido a la mujer existir, expresarse y en la que incluso se le ha impuesto vivir una relación no mediatizada con la realidad. [...] lo cotidiano es al mismo tiempo institución, es lo que aparece sin fecha, lo que se repite en un tiempo siempre igual; es un orden definido y modificado por constricciones externas [...]; existe sólo en la falta de conciencia y produce al mismo tiempo identidad formal e inseguridad profunda, afianzamiento y angustia oculta
\end{abstract}

(BRAVO Y SCARAFFIA, I979: 27)

\title{
INTRODUCCIÓN: \\ UNA ACLARACIÓN TEÓRICO-METODOLÓGICA
}

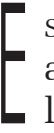
STE TEXTO SE CENTRA EN LA PRÁCTICA DE LA VIDA RELIGIOSA FEMENINA al interior de la clausura, la cual alude a las maneras en que las religiosas se apropiaron de las condiciones en que vivían, a sus experiencias y a sus modos de interpretación de lo normado (Lüdtke, I995: 49-69). La lectura crítica de algunos documentos conventuales como los libros de cuentas, los diálogos y biografías edificantes, los textos de las partituras interpretadas en el coro y, obviamente, la Regla clariana, permitieron observar cómo estas olvidadas y por ello marginales protagonistas de la historia neogranadina se relacionaron con lo establecido.

Práctica significa apropiación; en este sentido, y de acuerdo con Lüdtke "se deberá retener ese rasgo peculiar que se ha definido como la doble constitución de la realidad" (49)도. Las monjas neogranadinas hicieron su historia en unas condiciones dadas, pero la hicieron ellas mismas ${ }^{2}$. Para la historia de la vida cotidiana lo importante es esto último, contrariamente a la racionalidad planteada por el mundo técnico-científico para el que las condiciones dadas son lo decisivo. Abordar la historia de la vida cotidiana implica un enfoque específico del pasado en el que no intervienen los estadistas. Este artículo se concentrará más bien en la conducta diaria de las monjas, reconstruida en la tensión resultante entre lo normado y lo vivido, entre las condiciones dadas y la forma como ellas se apropiaron de las mismas 3 .

I. El autor hace esta afirmación citando a Hack, Lothar y otros.

2. El autor cita la clásica afirmación de Marx, "Los hombres hacen su propia historia, pero no la hacen voluntariamente, no en circunstancias elegidas por uno mismo, sino en circunstancias halladas, dadas y transmitidas" (Marx, I852: II5). 


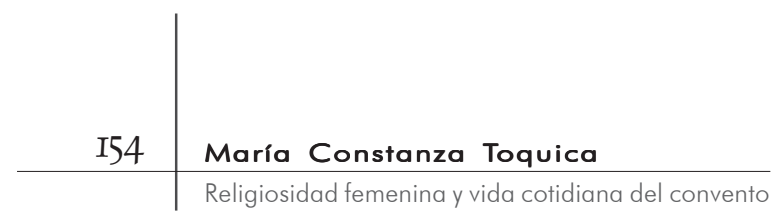

3. Este enfoque insiste en que cada hombre y cada mujer han "hecho historia" diariamente, en contraposición a la llamada ciencia social histórica para la cual "la dinámica histórica se situaba en las elites tradicionales o modernas, pero sobre todo en procesos anónimos socioeconómicos". El ser humano en masa aparecía como mera cifra estática o como un destinatario anónimo de exigencias o estímulos. "...el clima mental de la guerra fría con su exclusión de todo aquello que estuviera o pareciera estar relacionado con Marx o el marxismo había paralizado sensiblemente la capacidad y las ganas de innovación. [...] los historiadores de la República Democrática Alemana seguían deduciendo de forma muy mecánica la actuación de las personas a partir de las estructuras, de las circunstancias sociales o de la forma de producción dominante, al menos en los tiempos del capitalismo (de monopolio) y del imperialismo" (Lüdtke, I995: 5I-52)

4. El término corriente eclesiástica hace referencia a la pluralidad de formas en las que las mujeres y los hombres, religiosos y seglares, viven el catolicismo en un periodo y en una nación o región determinada. Es interesante anotar lo que Julio Caro Baroja dice al respecto : "[.....] faltan descripciones detalladas de diferentes experiencias religiosas que se dan, simultáneamente, en una nación, [....] los que dentro de ella, tanto como los de fuera, consideran homogénea y suficientemente caracterizada por notas como las de católica, española, de tal épo$\mathrm{ca}$, o protestante [....]. En las historias generales se suele dar por sentada esta homogeneidad, y a la descripción global siguen unos juicios también globales. Falta matizar en lo que se refiere al contenido de tales experiencias. Faltan también descripciones hechas sin propósitos apologéticos ni denigratorios. [....] de suerte que no puede reducirse a tal fe a unas cuantas ideas, por profundas y esenciales que se consideren, ni a unas cuantas prácticas rígidas, ni a un puro balance negativo, fundado en dos o tres sentencias más o menos antiguas y repetidas. [.....] podrían encontrarse posiciones parecidas de católicos del siglo XIX, manejando clichés del XVI, sin revisarlos" (Caro Baroja, 1995: 2I-22, 33).

Aparecen en sus múltiples y contradictorias situaciones, en la mezcla de yuxtaposiciones de sentimientos, cálculos, experiencias e intereses. La historia de la vida cotidiana significa también la reconstrucción de ciertas resistencias, se dirige contra una historiografía de los vencedores al dar voz a los olvidados, en este caso a las olvidadas de la historia.

Esta interpretación de la vida cotidiana de la clausura clariana se inscribe dentro de una investigación más amplia, que concibió al convento femenino neogranadino como una institución plurifuncional dentro de la sociedad local santafereña con la cual interactuó económica, social y políticamente. Todas estas interrelaciones se interpretaron, como lo plantea Michel de Certeau para la escritura de la historia de estos siglos, por medio del código de referencia religioso. El problema central que me interesó resolver fue esta plurifuncionalidad inscrita dentro de la corriente eclesiástica ${ }^{4}$ postridentina, observada dentro de una perspectiva histórica.

El convento femenino colonial fue el único espacio donde las mujeres de la elite pudieron vivir libres del yugo doméstico en una sociedad enteramente patriarcal. La valiosa producción de Francisca Josefa del Castillo, religiosa clarisa de Tunja, y otras obras femeninas inéditas son un indicio para pensar que el espacio de clausura favoreció la creatividad, la educación, la escritura (Robledo, I994) y el desarrollo de la inteligencia y la mística femeninas. En este caso, los 


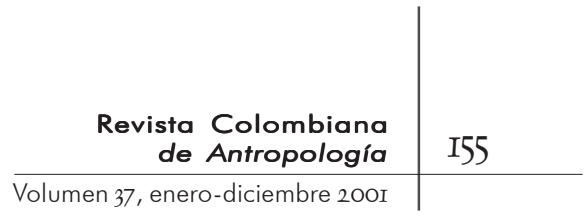

documentos sobre Johanna de San Esteban -clarisa del monasterio Santa Clara de Santafé- son una valiosa guía y un ejemplo de esas obras femeninas que ayudan a entender la vida cotidiana de la época y nos permiten ver del convento hacia fuera. Veremos cómo no todas las mujeres coloniales (Lavrin, I985: 93I), vivieron tan a la sombra de sus contemporáneos masculinos, como podría creerse; las religiosas, las viudas de la elite y las cabezas de familia de algunas castas formaron un grupo de población colonial en el que puede observarse cierta autonomía respecto a los hombres.

El convento fue una institución en la que confluyeron varias corrientes del cristianismo occidental, que modelaron diferentes formas de vida religiosa bajo patrones heredados de la antigüedad y del medioevo. Estas nuevas articulaciones se desarrollaron dentro de una fachada moderna y postridentina; modernidad homogeneizadora que desde Trento descalificó la gran variedad de expresiones religiosas femeninas y centralizó la Verdad por medio de un rígido entramado de normas que señalaron el camino hacia la perfección, para la debida consumación del matrimonio místico y, en el mejor de los casos, para el acceso a la santidad.

Los tres aspectos de la vida conventual que trataré son: I) Las condiciones de la forma de vida religiosa clariana; 2) La vida en comunidad; 3) La vida religiosa.

Reconstruyamos sintéticamente el túnel que traspasó los muros de la clausura e ingresemos a ese lugar vedado a los seglares, donde se desarrolló la vida cotidiana de las monjas y su particular religiosidad expresada en diversas prácticas.

\section{LOS INSTITUTOS DE PERFECCIÓN Y LA PRÁCTICA CLARIANA}

OS CONVENTOS FEMENINOS COLONIALES ESTABAN SEPARADOS DE LA sociedad civil únicamente por sus muros de piedra. Lejos de vivir aisladas y contemplativas, las monjas formaban parte activa de la sociedad. En ese contexto se dedicaban a sus prácticas religiosas, que no por esto eran menos intensas en su deseo de servir a Dios. La comparación entre los ideales de la forma de vida religiosa de la Regla clariana de I252 y los de las constituciones 
adoptadas cuatro siglos más tarde en el convento santafereño, en I622, muestra la diferencia de corrientes que bajo un mismo nombre se desarrollaron en la historia eclesiástica. En este caso, una medieval, guiada por la voluntad evangélica de la fundadora de la orden y la otra moderna, dirigida por la política contrarreformista postridentina.

La voluntad continua de extrema pobreza fue truncada diez años después de la muerte de la santa, en I263, cuando Urbano IV les permitió tener rentas y bienes, extendiéndose en normas minuciosas dirigidas a prevenir abusos y a encuadrar a las monjas dentro de un sistema de vigilancia contradictorio al clima de convivencia confiada de los inicios (Iriarte, I98I: I85). Pero más estrictas y minuciosas fueron las ordenaciones que escribió el arzobispo fundador, Fernando Arias de Ugarte, para las clarisas de Santafé y de Pamplona en I622 (Vances, I699: 226). Tal vez esto se debió al relajamiento vivido en algunos conventos de ultramar ${ }^{5}$ y al clima impuesto por el concilio de Trento (I545I563). Frente al protestantismo, el catolicismo reforzó el celibato

5." El contraste violento entre severidad y disolución aparece en todas las manifestaciones de la edad barroca y es común a todos los países y todas las clases. Muchas veces austeridad y relajación se dan en una misma alma [...] Pero el caso de la sociedad barroca del siglo XVII no es único: rigorismo y libertinaje, pesimismo radical y sensualidad exaltada, ascetismo y erotismo, son actitudes que generalmente se dan juntas" (Paz, I998: I05-IO6). incondicional de los religiosos y religiosas e intensificó la reglamentación de la vida monacal, atendiendo sobre todo a la observancia del voto de castidad.

Los monasterios postridentinos fundados en el nuevo mundo pretendieron ser un modelo de observancia que colaboraría con el desarrollo de la nueva cristiandad universal. En el plano espiritual, las reformas significaron la institucionalización y la profesionalización del perfeccionamiento individual por medio de la virtud. Los conventos se transformaron en verdaderos institutos de perfección, cuyo objetivo fue ahondar las diferencias respecto de las instituciones profanas y conquistar el monopolio de la santidad canonizada (Anderson y Zinsser, I99I: I9I), mediante una estricta Regla que guió la vida diaria de las religiosas. 


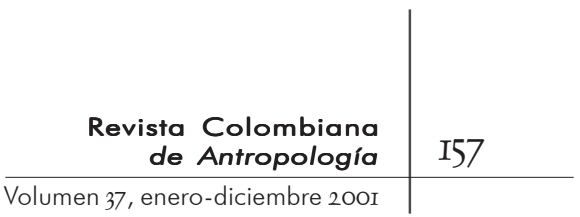

LAS CONDICIONES DE LA FORMA DE VIDA RELIGIOSA CLARIANA. LA LIMPIEZA DE SANGRE

T A CONDICIÓN A PRIORI EN LA ELECCIÓN DE LAS MONJAS DE VELO NEGRO $\downarrow$ que ingresarían al convento era de carácter social: estaba determinada por la limpieza de sangre. La escritura fundacional del convento (ACSC, Registros y protocolos) y el breve de Urbano VIII (Vances, I699: II-43), señalan que las doncellas debían ser nobles pero también virtuosas. Como “Obra Pía” (ACSC, Registros y protocolos, fols. 3v-4r tercera cláusula) debía recibir a aquellas que además fueran pobres "Doncellas qe. Por falta de remedio padecen muchos trabajos, y riezgos" (fols. Ir-v). El argumento central que el Papa esgrimió en la bula de la fundación fue su carácter social como ente protector del sexo femenino. Para él, la mujer era un ser indefenso, más aún si vivía en "una ciudad y Diócesis [...] pobre”. Por ello lo más apropiado era la construcción de un monasterio destinado a "algunas doncellas pobres" (Vances, I699: I9-20). Sin embargo, en la práctica allí no sólo vivió esta clase de doncellas, también lo hicieron huérfanas ricas como Johanna de San Esteban, de quien su biógrafo, el presbítero Martín Palacios, resalta su linaje, pero además, de acuerdo con su carácter ejemplificante, su nobleza, ya que según él era "una [...] virgen prudente cuia lampara ardía con el pábulo de la fe, esperanza y caridad” (ACSC, Colección de la vida exemplar, fols. Ir-v).

\section{El número de religiosas y las condiciones de recepción de las novicias}

\footnotetext{
A LGUNAS SANTAFEREÑAS PROFESABAN PORQUE ERAN OBLIGADAS POR sus padres, por un desengaño amoroso, para evitar un matrimonio no deseado, por una mala situación económica, soledad o vínculos afectivos con parientas y amigas, como lo escuchamos de boca de la religiosa del Diálogo, inventado con fines pedagógicos:
}

las mas de las Religiosas no tuvieron mas vocacion, qe. el afecto de carne, y sangre, ó el empeño. [...] Muchas de nosotras criad[a]s en el 
Monasterio nos aficionamos de tal modo a la Tía, a la Amiga, a la hermanita, a n[ues]tra Maestra, o á algun otro Ydolo [...], y este afecto no nos deja despegar de ellas, [...] (ACSC, Diálogo entre un confesor y una religiosa, fol. 24v).

Según la escritura fundacional y la bula de Clemente VIII, no podían ingresar más de veinticuatro religiosas profesas, cada una con una dote de dos mil pesos de oro y su ajuar (Vances, I699: I86-I87). Además, en la autorización de la profesión de la doncella debían primar sobre las aficiones particulares "el servicio a Dios y la utilidad del convento". No podían entrar hasta que sus padres o acudientes pagaran la suma (Ibidem: I9I-I92). Antes de profesar la abadesa o la vicaria le informarían de "la azpereza de la vida" y de sus obligaciones. De acuerdo con Trento, profesaría después de un año de noviciado (Ibidem: 189-90). Debía tener buena fama, ser sana de "cuerpo y apta para llevar los trabajos de la Orden”. A los once meses la novicia diría en el refectorio la doctrina cristiana y sería examinada en el oficio divino, "con testimonio de la Maestra, [...] y de las Examinadoras [...] de su suficiencia [...]". Entonces se tomarían los últimos votos secretos (Ibidem: 193), previa confirmación de tener dieciséis años cumplidos (Ibidem: 193-I94).

Johanna de San Esteban profesó el I3 de diciembre de 1662, día de santa Lucía. Para consagrarse a su celestial esposo se preparó con "asperezas, ayunos, oracion, y meditación”, corriendo "al mismo paso que volaban sus encendidos y fervorosos afectos”. Durante diez días hizo los ejercicios de san Ignacio de Loyola, práctica que aficionaba "la virtud", reformaba las costumbres y era "el molde de hacer santos" (ACSC, Colección de la vida exemplar, fol. I6r). Fray Joann de Arquiano, arzobispo de Santafé, le recibió sus votos monásticos (fol. I6v). El ritual de la profesión estaba enmarcado dentro de una ceremonia religiosa con música y canto, como lo prueba una partitura inédita, "A un hábito. Cava hortelana", que contiene un cuarteto compuesto "para la profesion de religiosas", escrito en 1702 (ACSC, Cuarteto del Maestro Herrera). 


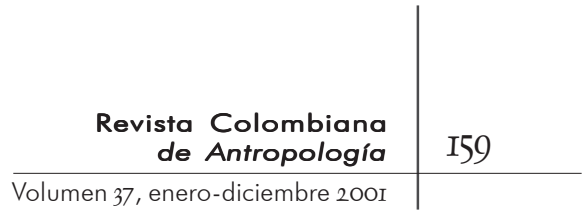

Los votos de obediencia, pobreza, castidad y clausura

\section{LA OBEDIENCIA}

EL CAMINO DE LA PERFECCIÓN ESTABA GUIADO POR LOS VOTOS, Y EL DE LA obediencia fue el que facilitó el control eclesiástico sobre las religiosas. El tiempo monacal, estructurado alrededor del oficio divino, fue marcado por el cumplimiento de los votos religiosos y el desarrollo de una personalidad extraordinaria (Lavrin,I993: 29), como la de Johanna de San Esteban (ACSC, Colección de la vida exemplar). Según el texto del Diálogo este voto era el principal y más grato, que podía ofrecerse a Dios, porque: "quando con la pobreza se le ofrecen los bienes del mundo y con la castidad los placeres del cuerpo; con la obediencia se le ofrece la libertad, qe. es cosa mas noble, y la mas preciosa, qe. tiene el hombre[...]" (ACSC, Diálogo entre un confesor y una religiosa, fol. gr).

El incumplimiento de este voto, fundamental para el control eclesiástico, implicaba la condenación eterna y el sacrilegio. Una monja profesa se sometía a dos autoridades: la abadesa y el confesor. Entre ellos existía cierta rivalidad, pero, en últimas, el confesor como director espiritual era el norte de las monjas, él decidía si las religiosas progresaban o no en su vida espiritual y medía la ortodoxia de su fe ya que podía denunciarlas a las autoridades (Madre de Dios, 1984: 374, 386-387). Las abadesas debían obligar con pena a sus monjas a ir a rezar al coro, a comer en comunidad, podían prohibir las diversiones profanas como los bailes y los disfraces de hombres y de matachines. Debían mandar que en los tornos y porterías no se estuvieran "ratos enteros perdiendo el tiempo en conversacion[e]s inutiles, y tal ves maliciosas". Tenían que hacer guardar el silencio conveniente y necesario.

Debido a que el texto de este diálogo es una adaptación de la Regla a las circunstancias específicas de la comunidad local, observamos por medio de lo prohibido algunas de las costumbres cotidianas de las clarisas, que la Iglesia pretendía corregir. El final de este coloquio dibuja retóricamente el tormentoso paisaje imaginario de las consecuencias de la desobediencia y el 
pecado, construidas desde el discurso misógino del poder eclesiástico, pero también deja ver rasgos del comportamiento de algunas religiosas: "si la comunidad se relaja [...] mucho fuego le aguarda en el otro siglo, [...] angustias, [...] rabiar, [...] desesperan[za] y tormentos sobre tormentos, [...] no se escapara de tales desdichas la Religiosa qe. resiste á su Prelada, la qe. la mormure, la qe. la censure” (ACSC, Diálogo entre un confesor y una religiosa, fols. [suplemento al fol. 9] r-v).

En esta compleja red, algunas formas de autoridad no se ejercían frecuentemente (Lavrin, 1993: 29). Los eclesiásticos en la cúspide de la jerarquía sólo visitaban el convento anualmente y entre ellos y sus súbditas existían intermediarios. Ello se constata en el capítulo "De extravahantes que se mandan" (Vances, I699: 2I7-226), escrito por el arzobispo Arias de Ugarte después de su visita al convento de clarisas de Pamplona en I622, y la carta enviada por la abadesa del monasterio de Santa Clara de Santafé al arzobispo de turno pidiéndole una dispensa sobre el número de criadas que podía enviar a la calle.

\section{LA POBREZA}

EL VOTO DE LA POBREZA FUE EL FUNDAMENTO DE LA PERFECCIÓN EVANGÉlica (ACSC, Colección de la vida exemplar, fols. 25r-26r) y la característica principal del carisma franciscano desde su origen (Iriarte, I994: I7-2I). La forma de vida del monasterio clariano, como la de muchos hispanoamericanos (Campo, I977: 228-242; Benassy-Berling, I983: 36-55; Muriel, I992: I5-I6, I29-I46; Soeiro, I985: 203-228), no coincidía con la intención primitiva ${ }^{6}$. La voluntad

6. Fuera de los de España los más ricos eran los de México, Brasil y Perú. Aunque también existían otros muy pobres como el de las car-

melitas calzadas de San Juan en

Puerto Rico (Ramos, 1990). inicial había cambiado tanto que en el texto del Diálogo observamos los bienes que poseían algunas clarisas santafereñas: "baxilla de plata, alajas presiosas [...], Escaparates dorad[o]s, cajones de Niños cargados de dijes, sabanas muy finas, Habitos de generos preciosos, [...] además de legad[o]s y Rentas" (ACSC, Diálogo entre un confesor y una religiosa, fols. IOv-I3r).

La pobreza se consideraba en particular, mas no en comunidad. Sin embargo, los réditos anuales del dinero legado por los padres podían ser usados "refundiendolos en la masa total de la Comunidad, ó en manos de su Prelada" (fol. IIv). Los dineros de la comunidad le permitieron "acudir al sustento, vestuario, y 


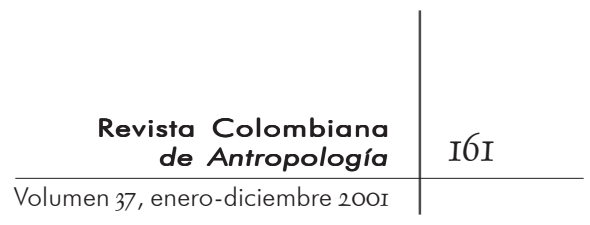

medicina de las Religiosas”. Para los gastos diarios la Regla les permitía "tener en su caxita dinero hasta quatro ps. y gastarlos en esas menudencias diarias" (fol. I2r). Pero la realidad era muy diferente: la religiosa inventada del texto del Diálogo evidencia en su confesión que allí esas condiciones no se daban. Cada una arbitraba sus pensiones y las empleaba en cosas de su gusto, no se reparaba en buscar cosas superfluas, como hábitos preciosos y muebles curiosos. El confesor las amenazaba, entonces, con la condenación, la ex comunión y con la consecuente privación de sepultura eclesiástica.

\section{LA CASTIDAD}

Joan Bauptista de Toro, el último confesor de Johanna de San Esteban, afirmaba que ella:

no fue menos aventajada en la virtud de la pureza, [...] que mas parecía de un espíritu Puro, que [...] una criatura humana. Como enemiga que [...] aborrecía el vicio que a la pureza se opone; le hacía sangrienta guerra [...] con cilicios, diciplinas, y varios generos de mortificaciones, las cuales suspendio [...] quando llegaron a ser los años muchos, y las enfermedades no pocas (ACSC, Colección de la vida exemplar, fol. 46r).

La idea de que las religiosas debían actuar como muertas en vida las hacía renunciar, sobre todo, a los placeres sexuales. Los ayunos y las flagelaciones eran los mejores instrumentos para resistir las tentaciones de la carne (Rubial, 1995: 355). El confesor del Diálogo advertía “[...] qe. [para que] la Virginidad sea entera, es preciso que jamas haya sido obscurecida ni el alma p[o]r algun mal pensam[ien]to ni el cuerpo p[o]r alguna acción criminal” (ACSC, Diálogo entre un confesor y una religiosa, fols. I4V-I5r). La castidad era "Angelica flor [que] con la mas leve mancha se aja, y marchita. [...] si no quiere qe. los enemig[o]s le roben este tesoro, cierre las puertas de los sentid[o]s guardando toda modestia, honestid[a]d, moderacion, y sobriedad en ver, oyr, hablar, comer, beber, y tocar" (fol. igv).

Para Michel Foucault (Foucault, 1985: 25), el siglo diecisiete sería el comienzo de una edad de represión; a partir de ese momento nombrar el sexo "se habría tornado más difícil y costo- 
so". Como si para dominarlo realmente hubiese sido necesario primero "reducirlo en el lenguaje, controlar su libre circulación en el discurso, expulsarlo" de lo dicho y "apagar las palabras que lo hacen presente con demasiado vigor". Aparentemente esas prohibiciones tendrían miedo de nombrarlo. El pudor moderno lograría que no fuera mencionado gracias al juego de las prohibiciones que se remiten unas a otras: "mutismos que imponen el silencio a fuerza de callarse. Censura”.

Dentro del discurso del Diálogo el voto de castidad recibió más atención y espacio que los otros. Los aspectos relacionados con el sexo fueron los más nombrados, sin nombrarlo directamente; esto hace presumir que fue uno de los temas más inquietantes para la Iglesia. En la reglamentación de este voto es posible interpretar dos componentes: uno es el control de los sentidos para poder preservar la pureza del cuerpo, de la mente y del alma. El otro es el matrimonio místico con Cristo (ACSC, Diálogo entre un confesor y una religiosa, fol. I4v).

La clarisa imaginada prometía apartarse de la portería y de los locutorios porque decía conocer lo dañosas que eran a su castidad "las miradas a los de afuera". Preguntaba si era menos grave "mirar p[o]r los a[g]ujeritos de las puertas, o tornos", a lo que el confesor le respondía, en clara referencia a la forma como se alimentaría el imaginario de la religiosa de imágenes "no castas", que:

si su R[everend]a mira de intento á un hombre, ninguna escusa tiene, con decir, qe. fue pr. un a[g]ujero, ó por la puerta abierta. [...] se llenan de tinieblas, los qe. miran pr. A[g]ujeros. Aquel tanto aplicar el ojo a los a[g]ujer[o]s qe. miran a la calle, ó a la Yglesia, llenan la imagina[cio]n de una Religiosa de tenebrosos fantasmas. Y [...] al rezar el Oficio Divino, en la Oracion y demas exercicios de Comunid[a]d le andan revoloteando en la mente las imagenes de lo qe. vio. [...] su alma debe estar como un christal mui limpio, en que se mire el Divino Esposo [...] (fols. 2or-v).

Según Foucault, las cosas aparecen muy diferentes respecto a la censura: "hay una verdadera explosión discursiva en torno y a propósito del sexo", pero con una depuración "rigurosísima" del vocabulario autorizado. Es posible que se haya codificado toda una retórica de la alusión y la metáfora. "Nuevas reglas de decencia filtraron las palabras: policía de los enunciados", y control también de las enunciaciones: se definió cuándo y dón- 


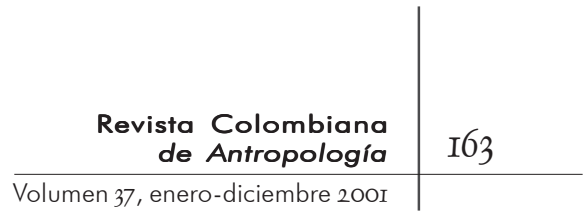

de era posible hablar de sexo, en qué situación, entre qué locutores y en cuáles relaciones sociales; así se establecieron regiones si no de absoluto silencio, al menos de tacto y discreción: entre padres y niños, por ejemplo, o educadores y alumnos, patrones y sirvientes (Foucault, I985: 25-26). Y qué no decir cuando se trataba de la educación religiosa de una monja enclaustrada, impartida desde el poder eclesiástico. En el discurso el fenómeno es casi inverso; el tema sexual no cesa de proliferar: una fermentación discursiva que según Foucault (26) se aceleró durante el siglo dieciocho, esencialmente en el campo del ejercicio del poder mismo: incitación institucional a hablar del sexo en detalle. Así lo demostró la evolución de la pastoral católica y del sacramento de la penitencia después del concilio de Trento. Poco a poco se vela la desnudez de las preguntas formuladas en los manuales medievales y en la mayoría de los del siglo diecisiete. Se evita entrar en detalles. La discreción se recomienda con más y más insistencia. Pero la extensión de la confesión y la confesión de la carne no dejan de crecer bajo el impulso de la contrarreforma. El director espiritual del Diálogo, llevando hasta el extremo los cuidados que debían tenerse con la provocación sexual incitada mediante las "malas artes de los hombres", advertía a la religiosa cómo la pintura, la poesía, la literatura, las imágenes de santos y hasta textos teológicos atentaban contra su castidad:

las pinturas, los libros de moda, y otros papeles pueden ser incentivos de luxuria. [...] Esos Payses llenos de Damas medio desnudas, y de Galantes, esos libros llenos de agudezas [...] de amores profan[o]s. Esas comed[ia]s y Entremeses son un veneno mui activo, qe. abraza el corazon. Ciertos retratos de Santos tal ves no son de Sant[o]s ó no son retratos Santos. Ciertos libros Teologicos tal ves tienen ellos la ponzoña escondida pa. matar el alma, y quisa no $\mathrm{p}[\mathrm{o}] \mathrm{r}$ culpa de quien escribe; sino de quien lee. De todo esto guardese mucho su Ra. si quiere guardar castidad, y sepa, q. casi tod[a]s las tentacion[e]s entran $\mathrm{p}[\mathrm{o}] \mathrm{r}$ la vista. [...] El Demonio acomete a la vista, pa[ra] pasarla al pensamiento y despues hacer su camada en el corazon [...] abomine de los engañosos deleytes, qe. le brinda el Diablo en esos libros lasciv[o]s [...] (ACSC, Diálogo entre un confesor y una religiosa, fols. 2OV-2Ir).

Según estas advertencias, las religiosas no hubieran podido instruirse en nada diferente de lo que tenía que ver con el oficio divino. ¿Cómo hubiera sido entonces posible la existencia de 
una sor Juana Inés de la Cruz? ¿Cómo se hubiera podido ir construyendo el conocimiento y el cultivo de las artes y de las letras dentro de los claustros femeninos?

El tacto asociado directamente a la sensibilidad sexual y ligado al placer carnal también fue normado estrictamente. Las advertencias del confesor dejan entrever la forma como algunas religiosas se saludaban con los hombres en el locutorio, poniendo en boca del Espíritu Santo una creencia patrística que consideraba a la mujer impura por naturaleza:

[...] no puedo tener $\mathrm{p}[\mathrm{o}] \mathrm{r}$ nimiedad los tact[o]s y abrazos de la Religiosa especialm[e]te con personas de otro sexo; sino, q. me atengo a lo qe. dice el Espiritu

7.El subrayado es del original. Sto. El hombre qe. tocare a la muger, no puede dejar de quedar manchado. ....] San Basilio [...] dice: que las vírgenes deben ser en esto muy recatadas: $\mathrm{p}$ [o]r qe. el tocamiento libre, aunqe sea de una mano sola es bastante, pa. alterar los sentidos, y hacerlos consentir en algun deleite [...] (fol. I5v).

Advertía también a la religiosa que se guardara mucho, porque "lo que suscede a la paja en la candela suscede a los dos sexos en tocandose" (fol. I6v). Es la primera vez en el texto que se nombra lo innombrable. El planteamiento de Foucault lo corrobora Gruzinski cuando afirma que durante el siglo diecisiete aumentó el interés eclesiástico por controlar el impulso sexual. Los confesionarios de la época ampliaron sus preguntas sobre el particular y tanto las investigaciones como las descripciones de todas las posibilidades de pecar sensualmente fueron cada vez más precisas (Lavrin,I993: 40). Pero no sólo había que controlar el contacto entre los dos sexos. Era preciso cuidar también los contactos entre las mismas religiosas. Por ello el confesor advertía sobre las amistades singulares entre las monjas:

[...] Estas amistad[e]s. melosas, muchas veces ocasionan la turbacion de la comunid[a]d. [...] Una sola amistad imprudente desacredita una comunid[a]d entera [...] sacrifiq[ue]n á su Divino Esposo todos sus afectos. Vivan en amistad evangelica, amense en hora buena pero huyan de la amistad singular (ACSC, Diálogo entre un confesor y una religiosa, fol. I9r).

Trataron de evitar el tacto corporal cotidiano, según lo esti- 


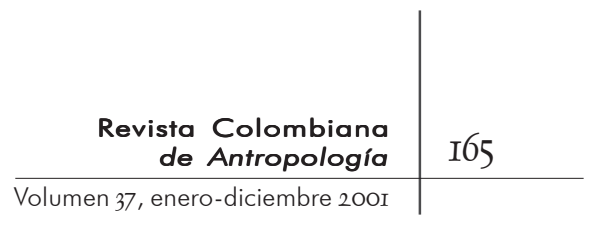

pulado por la regla, obligando a las monjas y a la abadesa a dormir en dormitorios donde las camas estuvieran "distintas y apartadas una de otra” y prohibiendo que durmieran dos "en una misma cama”. Las monjas no podían dormir acompañadas "una con otra, ni [...] desnudas de sus habitos, ni desunidas" (Vances, I699: I8I-I82). La sensibilidad personal fue limitada visual y físicamente mediante el uso de ropa especial (Loreto, I995: 546). El control de los afectos de las religiosas se extendía a las criadas y a las seglares. Algunos apartes del Diálogo develan los juegos que tenían las religiosas de clausura entre sí y con las demás, los cuales eran asociados al comportamiento de otros grupos raciales y del otro sexo.

El control de lo que se hablaba y de lo que se escuchaba era tan importante que existía el oficio de las escuchas. Las constituciones (Vances, I699: I5I-I52) estipulaban la vigilancia de las religiosas que iban a conversar al locutorio para luego contar a la abadesa lo escuchado.

Mediante el control de los sentidos la religiosa lo que hacía era prepararse para el objetivo final: el desposorio místico con Cristo, para el que era requisito básico el voto de castidad. El cuerpo femenino fue considerado como propiedad del esposo. La metáfora del desposorio místico que inspiró una forma de religiosidad claramente femenina, se remonta al siglo trece, y en el diecisiete fue interpretada como una realidad física con connotaciones patriarcales: Cristo era un marido celoso y sus esposas debían guardarle fidelidad. La ruptura de esta promesa, que en las laicas se llama adulterio, en las religiosas se denominó sacrilegio (Rubial, 1995: 356). La relación personal de la religiosa con su esposo fue un elemento clave del discurso religioso que sirvió a los biógrafos para reforzar el modelo patriarcal en las relaciones de género. En este contexto, en el Diálogo Jesucristo era mostrado como un marido celoso y a las religiosas como esposas necias e infieles.

[...] Ver unas Niñas bien criadas en su casa, [...] despues de Relig[iosa]s con la nueva obligación [...] verlas ya sueltas en visitas secular[es] á mañana, y tarde sin recato, sin modestia. Ver á esa Paloma darle sus brazos, apretarle la mano al Gavilan. Verlo á el fuera, y ella adentro sentad[o]s juntos tocandose la ropa [...] (ACSC, Diálogo entre un confesor y una religiosa, fol. I6r). 


\section{LA CLAUSURA}

Cuando Johanna de San Esteban se enfermaba no Permitía la entrada de ningún médico, para no ser vista por extraños, y si la dolencia no era muy aguda decía que podía curarse con un remedio conocido (ACSC, Colección de la vida exemplar, fol. 42r). Contrariamente a la poética interpretación de Octavio Paz sobre la clausura de sor Juana Inés de la Cruz, la religiosa del Diálogo solía escuchar a algunas de sus hermanas decir: "Cosa recia, terrible cosa! un cuerpo y alma, y los sentid[o]s debajo de tantas llaves y algunas mui duras, que no se pueden falsear". De acuerdo con la Regla y las ordenaciones, el voto obligaba a no salir "nunca jamas" de la clausura interior, salvo en caso "de incendio, peste, ó enfermedad contagiosa o tener que salir á fundar Monasterios” (ACSC, Diálogo entre un confesor y una religiosa, fol. 2Ir). Pero para vivir en observancia no sólo era necesaria la clausura del cuerpo sino también la del alma.

[..] Una clausura abrazada $\mathrm{p}[\mathrm{o}] \mathrm{r}$ inspiracion del cielo es un Jardin de espirituales delicias; pero faltando esta es una carcel de arrepentid[a]s. La continencia ofrecida solo $\mathrm{p}[\mathrm{o}] \mathrm{r}$ voto esta mui expuesta á quebrarse. El claustro, qe. pa[ra] las llamad[a]s. es Huerto de delicias, es pa[ra] las violent[adas] sep[u]ltura horrorosa de vivos (fol. 24v).

\section{LA VIDA EN COMUNIDAD}

I A VIDA En COMUNIDAD ESTUVO MARCADA POR LA REgLA QUE SEÑaL laba las jerarquías y los oficios conventuales, que de una forma u otra reproducían en el convento la división social existente. Los dispositivos de seguridad, establecidos especialmente en las constituciones arzobispales de Arias de Ugarte, son detallados y extensos; por su intermedio todas se convertían en vigilantes de sí mismas y de sus hermanas. Prácticas cotidianas como el comer se transformaban en rituales religiosos, enmarcados en prescripciones que tenían que ver con el silencio, la antigüedad, la moderación y el castigo de la culpa. Cada lugar del monasterio estaba destinado a un cometido particular que tenía que ver con la cotidianidad normal, pero también con sig- 


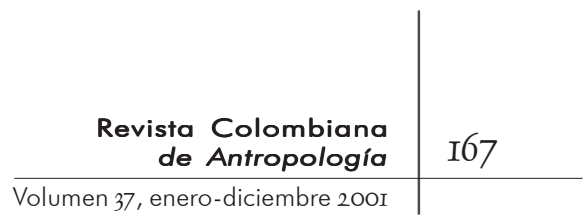

nificados de la vida religiosa propiamente dicha. Las condiciones explícitas para desempeñarlos eran sobre todo morales.

\section{Las jerarquías y tareas}

\section{EL GOBIERNO DEL MONASTERIO}

LA ABADESA, LA VICARIA, LAS DISCRETAS Y LA NOTARIA, ESTOS CUATRO cargos ejercían las tareas de mayor responsabilidad. Debían desempeñarlos personas cuyas decisiones tuvieran influencia en la comunidad durante un trienio, tiempo del gobierno conventual. Al terminar, la abadesa renunciaba para dar paso a la nueva, que se elegía por medio de votos secretos de toda la comunidad (Vances, I699: I38). Para alumbrar "los entendimientos de las

8. "Y las Religiosas procuraran elegir Abadeza de mucha virtud, religion, $y$ honestidad, $y$ de talento para governar prudente, y suavemente: de hedad de quarenta años y que aya ocho que es profesa $[\ldots]$ conforme al dicho Santo Concilio Religiosas"8, desde siete días antes de la [...]" (Vances, I699: 139). elección se oficiaba una misa diaria al Espíritu Santo.

La abadesa tenía que penitenciar, corregir y castigar; así mismo, debía "proveer las necesidades temporales de las Religiosas, con amor de Madre”, con igualdad y discreción religiosa. Todas las noches debía visitar el dormitorio y las camas, haciendo que cada una durmiera en la suya; debía revisar que las puertas estuvieran cerradas y todas las noches guardar las llaves de éstas, de las rejas, de los locutorios y tornos "con particular cuidado"; estaba obligada a acompañar a los confesores, médicos, cirujanos y barberos desde que entraban hasta que salían del convento, con dos religiosas, en lo posible porteras y ancianas; al entrar tañerían las campanas para que las monjas se recogieran. Una abadesa debía ser "en el mandar venigna, en el reprehender, zelosa, y solicita, en el penitenciar a sus hijas, justa, y benevola, y en el proveer a las necesidades del Convento diligente, y caritatiba" (Ibidem: I4O-I42).

Como se observa en los libros de cuentas del monasterio, en diversas ocasiones éstos fueron escritos por las abadesas. De la muestra de catorce libros de cuentas estudiados once fueron 
llevados por abadesas, la mayoría de ellos escritos de noviembre a noviembre, mes en el que finaliza el año litúrgico.

Todas las ex abadesas podían ser perpetuas discretas; después de la abadesa y de la vicaría tendrían los primeros lugares. Cuatro discretas formaban el definitorio, según su antigüedad. Con su consejo y con la asistencia del prelado, la abadesa decidiría las cuestiones económicas más importantes, como los contratos de compraventa, arriendos y cuentas (Ibidem: I46-I47).

\section{LA EDUCACIÓN CONVENTUAL:}

LA MAESTRA DE NOVICIAS Y LA VICARIA DEL CORO

LA MAESTRA DE NOVICIAS DEBÍA SER PRUDENTE Y CELOSA EN EL CUIDADO de sus novicias, leerles la Regla y enseñarles lo que debían hacer en las ceremonias religiosas, en el Oficio Divino, tomándoles cada día cuenta de lo que habían aprovechado en la oración. Las dirigiría y encaminaría en la oración con piedad y caridad e iría mortificando a cada una según las fuerzas espirituales que tuvieren (Ibidem: 159). En este método y en las labores desempeñadas por la abadesa y la vicaria del coro se observan los lineamientos del inicio de la pedagogía femenina desarrollada en los conventos de monjas antes de que existieran los colegios para mujeres propiamente dichos.

La maestra de novicias debía enseñar a sus alumnas desde el altar, donde celebraría los capítulos. Al dormir las reuniría en el dormitorio de la comunidad. Debían rezar en el oratorio todos los domingos y las vísperas de difuntos. Los lunes el primer nocturno, los martes el segundo, los miércoles el tercero, los jueves las laudes del mismo oficio, los viernes los salmos penitenciales y los sábados los graduales. Los días en que no se rezara en el coro el oficio menor de "Nuestra Señora”, lo harían en el oratorio, devotamente (I60). Durante dos años las novicias estarían bajo la disciplina de la maestra, quien las nombraría cantoras, versicularias, para que leyeran en la mesa del refectorio y movieran los libros (I6I). Para enseñar a las novicias a ser humildes y obedientes, todos los viernes la maestra les haría decir sus culpas en el refectorio (I62).

9. Proyecto para elaboración de CD en curso.

A la vicaria del coro le correspondía "el cuidado grande, [...] de 


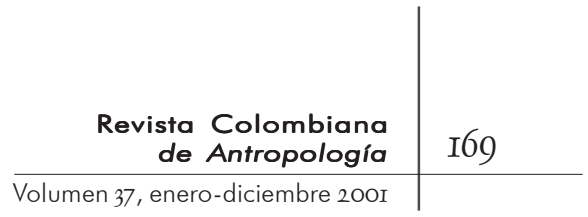

que el Oficio se cante [...] haziendo se diga con la devida pauza, comenzando todas juntas, y acavando a un mesmo tiempo, para que aya uniformidad, y consonancia, teniendo gran cuidado, en que las Religiosas, ayuden al Coro, en lo cantado, y rezado" (I57). Gran cantidad de partituras (ACSC, Colección de partituras) confirman la actividad del coro de Santa Clara9 ${ }^{9}$ Las canciones interpretan el Kirie leison o "Señor ten piedad" -que las religiosas entonaban al comienzo de las misas-, dúos, tríos y cuartetos de villancicos, música para la profesión de las religiosas, para la virgen María, el niño Jesús y el santísimo sacramento.

\section{LA VIGILANCIA DEL COMPORTAMIENTO CLAUSTRAL}

LA PORTERA, LAS ESCUCHAS Y LA CELADORA: LLAVES CELOSAMENTE GUARdadas, ojos y oídos delatores. Durante el gobierno de Johanna de San Esteban fue necesario dejar entrar a unos oficiales de albañilería para realizar algunas obras en el convento. Para ello existía una puerta aparte que daba paso a la clausura (ACSC, Colección de la vida exemplar, fols. $23 \mathrm{r}-\mathrm{v}$ ), que cuidaba como portera una religiosa de celo y conocida virtud, a pesar de lo cual la madre Johanna tuvo noticia que un hombre visitaba frecuentemente a una religiosa. Este hecho produjo en la abadesa "un triste melancolico sentimiento" que le causó "fuertísimos dolores".

La portera se elegía entre las religiosas más ancianas, guardaba una de las llaves y abría la puerta para entrar las cosas que no cabían por el torno. Vigilaba que nadie hablara o negociara en las puertas del convento "sopena de privación de los [...] oficios, y de un mes de carzel” (Vances, I699: I47-I48). Además, recibía por el torno los recados enviados a las monjas. Las cartas, los papeles o billetes serían entregados a las religiosas después de avisar a la abadesa. Ninguna monja podía acercarse al torno sin permiso de la prelada y sólo podían hacerlo para recibir los recados y dar respuestas breves a través de las torneras. Durante las horas de oración, de la misa y de la comida, las puertas internas de los tornos y de las rejas debían estar cerradas con llave (Ibidem: I49-I5I).

Ninguna monja podía hablar, ni siquiera con sus padres, sin la presencia de la escucha asignada, que debía vigilar que en el locutorio no se hicieran comidas de festejos y que las monjas 
no metieran la cabeza entre los velos y la reja, para no ser oídas. Deberían ver y oír lo que hacían y hablaban para informarlo enteramente a las superioras (Ibidem: I5I-I53).

A la hora nocturna del silencio la celadora cerraría las puertas internas de la casa y daría las llaves a la abadesa. En el dormitorio, antes de cerrar la clausura, tenía que estar atenta con las religiosas que salieran "a las necesidades" para que volvieran pronto, y en lo posible las acompañaría por "excusar los inconvenientes que pueden suceder de ir sola". También recogería y contaría "todas las Chinas, y gente del servicio" para decirles la doctrina cristiana. A la mañana las haría salir para que cumplieran sus obligaciones (Ibidem: I53-I54).

\section{EL CUIDADO DE LO SAGRADO: LAS SACRISTANAS}

RECORDANDO EL PAPEL DE LAS DIACONISAS, LAS SACRISTANAS SERÍAN "DE Gobierno" para cuidar las cosas de la iglesia, y "mirar que se sirva a Dios Nuestro Señor, con devoción, curiosidad, y limpieza, teniendo los ornamentos tocantes al culto divino, y particularmente los Calizes, Corporales, y Aras, con mucho azeo, y veneración, y que las Hostias, y el vino esten muy a recaudo, y sus vasijas, Hostiarios, y Vinageras, muy limpias" (Ibidem: I55).

Mantendrían siempre la luz delante del Santísimo Sacramento, proveyendo con tiempo lo necesario para ello. Llenarían constantemente con agua bendita las pilas de la iglesia y de la clausura. Los domingos rociarían toda la casa con agua bendita. También serían las encargadas de mandar tocar las campanas puntualmente, proveer en la mañana lo necesario al sacristán y recibirlo después de la misa por el torno que sale a la capilla mayor de la iglesia. Asearían y limpiarían "con curiosidad" los altares "como conviene a tan santo lugar" (I55-I56).

\section{EL CUIDADO DE LA SALUD: LAS ENFERMERAS}

LAS ENFERMERAS DEBÍAN CURAR CON GRAN CARIDAD y PIEDAD. SE ASIGNArían dos religiosas solícitas que se encargarían de la ropa de la enfermería y de las demás cosas. En la enfermería no permanece- 


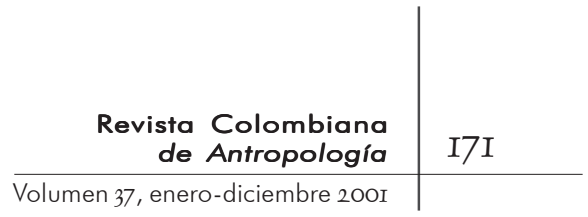

rían sino las religiosas que lo necesitaran según la prescripción médica. Las visitas serían breves. Estarían atentas a la gravedad de la enfermedad para avisar a la abadesa que debía hacer aplicar los Sacramentos, en caso extremo. Si la enfermedad era extraordinaria sería preciso que la abadesa hiciera reunir a la comunidad para orar por la enferma. Si "llegare a disposición de muerte", procuraría que asistieran a la moribunda las más religiosas para "que la animen en aquel estado". Si alguna religiosa moría compondrían el cuerpo de la difunta de la manera acostumbrada y se avisaría para que las campanas doblaran por ella mientras que la comunidad alistaba lo necesario para el entierro (Ibidem: 164-I65).

\section{LA ALIMENTACIÓN MONACAL: LA REFITOLERA \\ Y LA COCINERA, COMIDA A PUNTO Y BIEN ADEREZADA}

LA REFITOLERA TENÍA QUE SER CUIDADOSA Y LIMPIA, SE ENCARGABA DE que la comida estuviera hecha "a punto" y bien aderezada; tocaba la campana al mediodía y tenía el refectorio limpio y aseado; ponía los manteles y los demás servicios de las mesas; repartía el pan, ponía sal en los saleros y cuidaba de que hubiese agua en las tinajas. Se encargaba de proveer las mesas a la hora de comer y cenar, y al terminar estaría atenta a recoger lo que sobrase, recogería los utensilios del servicio del refectorio y los guardaría en sus alacenas y cajas (Ibidem: 166-167).

La cocina sería servida y administrada con limpieza y caridad por las personas señaladas por el convento. Una religiosa se encargaría semanalmente de supervisar que las comidas se aderezaran bien y "bastantemente”. Las que hacían los platos y preparaban las viandas deberían repartirlos equitativamente y sin excepciones. La abadesa y la vicaria estarían pendientes de esto para excusar las quejas de las religiosas, las cuales tendrían que contentarse con los platos que les pusieran, sin devolverlos "para que se les de más vianda, so pena de la porción que havia de tocar por un día". Ninguna de las "religiosas sirvientes legas, se atreva a volver el dicho plato, aunque cualquiera religiosa se lo mande, so pena de comer en tierra por un día” (Ibídem: I67-168).

A la cocina no tenía por que entrar ninguna criada o china a guisar las comidas ni a cocinar para las religiosas a las que ser- 
vían; las que lo hicieran estarían un día en el cepo. Si reincidían serían expulsadas del convento. Las cocineras debían tener la puerta de la cocina cerrada con llave, y si por algún caso "huvieren de dar algun plato, para afuera del refectorio, a algunas de las criadas, o chinas, lo den por las ventanillas de la puerta nueva que se hiziere" (Ibidem: 168).

\section{LA VIDA RELIGIOSA}

A VIDA RELIGIOSA LLEVADA EN UN CONVENTO DE CLAUSURA DEFINÍA desde la entrada de la novicia su forma de vestir, el tratamienL to de su cuerpo y su comportamiento en ciertos lugares como el dormitorio, el refectorio, las celdas y la sala de labores. Se tenían que someter a los horarios litúrgicos en los que se reunían para rezar y cantar el Oficio Divino y debían cumplir ciertas penitencias según la clase de culpas cometidas. Pero había quiénes, además de los rigores de la regla, se imponían cometidos más exigentes y estrictamente religiosos para lograr la perfección del alma y así poder acceder a su Esposo después de la muerte de la manera más pura. Como lo conocemos por la biografía de Johanna de San Esteban, éstas iban más allá por medio de sus experiencias místicas.

\section{El hábito y el cuerpo: austeridad y penitencia}

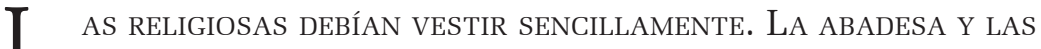
$\perp$ discretas podrían dispensar "en cuanto sea mas, o menos, la ropa" de acuerdo con la necesidad de la religiosa y según el tiempo y lugar lo demandaran. Al morir alguna religiosa, así fuera sobrina, parienta, maestra o discípula, sus bienes se debían entregar a la abadesa, vicaria y discretas para que dejaran lo necesario para el uso común del monasterio. Las demás cosas las repartirían entre las más pobres (Ibidem: 206).

Johanna de San Esteban decía de su vestido que "la camisa que usaba era, de lienzo el mas grosero, de aquel genero que solo se aplica, para enfardelar arina, y aun le parecía era mui delgado. El avito fue siempre, sayal muy basto y deslucido, mas para los ojos de Dios, que lubrica tan brillante; de semejante tunica usaba 


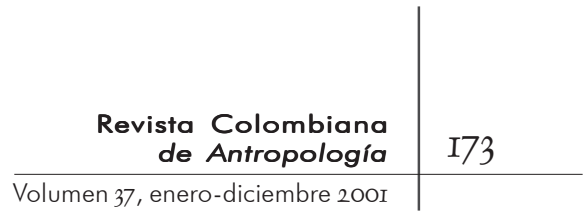

San Antonio Abad" (ACSC, Colección de la vida exemplar, fol. 29r). Según la doctrina de san Pablo, vivir según la carne causaba la muerte, pero mortificarla causaba la vida, en la interpretación del presbítero Martín Palacios. Esta doctrina fue la que siguió la V. Me. castigando su cuerpo, con áspera penitencia. Su cuerpo lo "adornaba lucidamente con un buen saco de aspero y duro cilicio, a que se añadía una cadena de hierro, que puesta desde el cuello bajaba en forma de cruz rematando los estremos en la cintura, y estos los unio con un candado, cuia llave no se halló, ni aun despues de su dichosa muerte" (fol. 29v).

Interpretado por el presbítero como un sacrificio de amor, Johanna de San Esteban pidió licencia a su prelada para ser sepultada con aquella cadena, porque "esclava de mi Sa. la Virgen, e de resusitar al fin del mundo, y si por grandíssimos pecados voy al infierno, o si por la bondad y misericordia de Dios subo al cielo, en cualquier destino quiero comparecer, con esta señal de esclava, acuía petición, enternesida la superiora le concedio tan humilde como inocente, pedimento" (fol. 29v). El presbítero resumía que la venerable Johanna era un cruel verdugo y enemigo de su cuerpo, porque además de las cadenas, los cilicios, el ayuno cotidiano y la continua abstinencia su cuerpo vivía extenuado con las habituales enfermedades de que adolecía, "en una naturaleza flaca y debil por su sexo" (fol. 3or).

A propósito de esta forma de tratar el cuerpo, Michel de Certeau afirma que en los siglos dieciséis y diecisiete, en el umbral de la modernidad, "la ambición de una radicalidad cristiana se dibuja sobre un fondo de decadencia o de 'corrupción', en el interior de un universo que se deshace y que es necesario reparar". La mística repite en la experiencia biográfica todo el vocabulario de la reforma eclesial: la división, las heridas, la enfermedad, la mentira, la desolación. "Los cuerpos individuales narran la historia de las instituciones del sentido. El fin del mundo es postulado por todas las poéticas espirituales. Sus trayectorias luminosas y arriesgadas marcan con sus trazos una noche [...]" (De Certeau, 1993: 24).

\section{El refectorio: lugar de purificación}

$\AA^{\text {l ser tañida la campana, todas las religiosas acudían solícita- }}$ 
mente a este lugar para estar presentes en la bendición de la mesa. Debían entrar con compostura y reverencia y ninguna podía levantarse sin dar las gracias. Mientras comían, una leería todos los días y noches, sin excepción, "un libro santo, y devoto”, señalado por la abadesa y la vicaria. Si tenían que salir por alguna necesidad o no podían asistir por enfermedad debían tener licencia de la superiora o declaración médica (Vances, I699: I76-I77).

Guardarían silencio y no hablarían sino por algo muy importante, en voz baja. La que presidiera dispensaría la guarda del silencio sólo en rarísimas ocasiones, durante las cuales las religiosas debían comportarse modestamente (Ibidem: 177-I78). La comunidad proveería "de manteles, cuchillos, platos, escudillas, y saleros, y de jarros”. En el refectorio habría una ventana por donde se recibirían la comida, los platos y vasos, y a su lado estaría la alacena donde se debían guardar (I78-I79).

El sitio donde se sentaría cada una sería asignado según su antigüedad, contándola desde los doce años, porque antes de esta edad, "no sirven a la comunidad, sino que son servidas". Este lugar también estaba determinado por el oficio. La norma de la comida conjunta en el refectorio tenía sus excepciones: cuando hacia el medio día Johanna de San Esteban terminaba su lección espiritual pasaba a su celdita que era muy pequeña o se quedaba en la más inmediata al coro, que era en la que vivía la madre Isabel de San Antonio, una religiosa de conocida virtud, con quien trataba. Allí comía con abstinencia cuando no era día de vigilia o ayuno. Su amor a la penitencia y su deseo de mortificarse, castigándose de muchas maneras, era tal que se sustentaba de un "pedacillo de cordero [y] tres raízes de arracacha con muy poca sal, ni composisión alguna” (ACSC, Colección de la vida exemplar, fol. 38r). En la noche sólo tomaba el agua de su cocinadura.

El refectorio era también el lugar donde se llevaban a cabo los castigos ejemplificantes, como comer en el suelo, debido a que dentro del imaginario conventual era un lugar simbólico de purificación. Todo ello hacía de la comida mucho más que un simple sustento físico; era también un alimento espiritual que convertía el acto de comer en un rito (Loreto, I995: 549).

\section{El dormitorio: lugar de silencio}




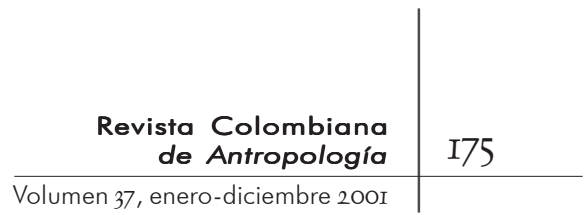

$\mathrm{D}$ ESPUÉS DE CENAR Y DAR GRACIAS LAS RELIGIOSAS SE RECOGÍAN EN SU dormitorio "cada una en su cama"; después de haber visitado todas las camas la abadesa cerraría la puerta de la clausura del dormitorio. La lámpara en medio del dormitorio nunca debía faltar, y permanecería bien cebada y encendida para poderlas observar. Después, la abadesa se recogería en su cama, ubicada en un lugar desde donde pudieran verse todas las camas "y juzgar" lo que allí se hacía (Vances, I699: I8I-I82). Allí no se podía comer, excepto las enfermas. Tampoco podían conversar, porque el dormitorio era "un lugar de silencio". Las criadas dormirían "cada una de por si, en cama distinta, y apartada" (Ibidem: I82). Johanna de San Esteban, ocupada en sus oraciones vocales, se acostaba a las once de la noche, vestida, sin que jamás se hubiera despojado del hábito, porque en este punto de la regla fue muy observante. Cuando se mudaba de hábito, inmediatamente se vestía para acostarse estrechándolo con el cordón, sin dejar de tener puesto el escapulario. Así pasaba hasta las dos o tres de la mañana, más recostada sobre las barandillas de la cama que acostada en ella, costumbre que observó hasta el día de su muerte.

\section{La celda: lugar de quietud y recogimiento}

ADA RELIGIOSA Y HERMANA DEBÍA TENER SU CELDA, QUE, EN TEORÍA,
no pertenecería a ninguna monja; sólo la usarían sin poderla
"vender, donar, ni enajenar, ni dejarlas después de sus días a sus
hermanas, parientas y amigas", porque eran del convento. Este
lugar no podía ser exorbitante, sino apto para recogerse, guardar
silencio y ocuparse en devoción y oración el tiempo que sobrara
de las tareas comunitarias, haciendo en aquel sitio de quietud y
recogimiento alguna labor de manos, los días que no fueran festi-
vos. De acuerdo con la orden papal de no recibir ninguna monja
si no había celda para ella, el arzobispo Arias de Ugarte exhorta-
ba a las religiosas para que todas procuraran hacer celdas y la
abadesa lo dispusiera para que fuera ejecutada según lo que su
santidad manda (Vances, I699: I83-I84). En la práctica esta regla no
se cumplió, como lo atestigua un documento de compraventa de
una amplia celda del convento de Santa Clara (AGN, Conventos).
Ninguna monja podía entrar en la celda de otra sin licencia de la 
abadesa, si lo hacía cometería “culpa grave”.

\title{
La sala de labor
}

A luí se reunían las religiosas a la hora asignada en las tardes A para hacer obras para la comunidad o según sus necesidades, siempre y cuando lo comunicaran a la superiora. Todo el tiempo que permanecieran allí una religiosa, según su turno, leería un libro de devoción (Vances, I699: I84-I85).

\section{El manejo del tiempo cotidiano}

F L TIEMPO DE LAS RELIGIOSAS EN LA CLAUSURA ESTABA ESTRUCTURADO ¿ alrededor de las horas canonicas, cuando se reunían para realizar el Oficio Divino. Quienes no desempeñaban ningún cargo dedicaban todo su tiempo a la oración. Johanna de San Esteban

\begin{abstract}
se levantaba todos los días [...] a las tres de la mañana, y [...] muchas veces a las dos, ya estaba en pie, inmediatamente rezaba la corona de la Ima. Virgen, y luego se ponía en oración hasta las sinco; [...] pasaba al coro, y se postraba a los pies de la Ymagen de Ntra. Sra. de donde se levantaba para ir a recibir la sagrada comunión que de orden de sus confesores, recibía cada día, [...] jamás comulgó sin haber hecho las referidas postraciones [...] despues gastaba un gran rato en dar gracias, hasta [...]la hora de rezar con la comunidad, las horas canonicas, [...] concluidas, bolbía a postrarse de rodillas pa. oír las missas, que se decían en su monasterio, cuía devocion era con mucho fervor, y ejemplo" (ACSC, Colección de la vida exemplar, fol. 37v).
\end{abstract}

Hasta el medio día continuaba con su lección espiritual, de la que sacaba materia para la oración mental. Ocupada en oraciones se acostaba a las once de la noche. La forma en que su biógrafo conceptualiza el tiempo y su relación no con el aumento de la ganancia sino de la virtud es quizás una de las diferencias básicas de la doctrina cristiana respecto a la práctica protestante del trabajo, aunque las diferencias estén marcadas más en el discurso que en la práctica, como se demostró por medio de las funciones económicas del monasterio. En el ejemplo de la vida 


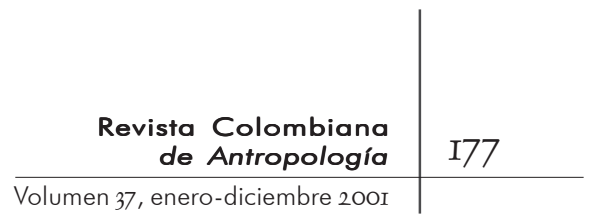

de esta religiosa es importante observar que se trataba de no perder el tiempo y de seguir la doctrina del evangelista san Juan, de "dar frutos en la vida, o al fuego leña": trabajar o arder. Porque el tiempo no se iba sino que huía, decía citando unas observaciones de Séneca sobre el pensamiento de Virgilio respecto al tiempo (fol. 39r). Y agregaba el presbítero que

nada se pierde en esta vida, de modo que no pueda repararse; si se pierde el dinero puede tal vez recobrase con ganancia, la salud perdida suele convaleser la honra quitada sirve tal vez de mayor aplauzo, a un dios perdido se deja hallar de la contrizion y penitencia; sólo entre todas las cosas el tiempo perdido no se dexa lograr otra vez, es irreparable su daño, es sin remedio su pérdida (fol. 39v).

La religiosa aprendió la forma de aprovechar el tiempo de la lectura de la vida de los santos, "que era la forma como ella se divertía" (fol. 40v). De acuerdo con la escisión cuerpo-alma tan propia del cristianismo, el biógrafo afirmaba que Johana de San Esteban no perdió el tiempo de su vida, porque lo ligó al trabajo, al trabajo en su perfección espiritual y en detrimento de su cuerpo, para alejar al demonio.

\section{La penitencia}

\footnotetext{
A DEMÁS DE LAS MORTIFICACIONES A LAS QUE VOLUNTARIAMENTE SE sometía, se añadía otra circunstancia que "le mortificaba su inocente corazón”. Johanna
}

no dejo de padecer notables persecusiones [...] había sido tenida [...] por religiosa Santa, pues hasta de ponerse en su presensia se avergonzaban, y temían las religiosas, porque [...] veía sus interiores [...] En el tiempo que havía sido Prelada, tomó a su cuenta una señora, el mortificarla, tratandole mal y tachándole sus acciones, sintiendo mal de ellas, y en fin causandole razonables disgustos, en publico [...] nunca bolbio por s[í] [...] ni se defendió, ni dio quexa la mas mínima, antes bien, diciendole una religiosa, que porque siendo superiora, toleraba tales cosas? (fol. 3Ir).

Su padecer interior, en el camino de su espíritu, que fue penoso y trabajoso, lleno de dudas, temores y "arideses", pade- 
ciendo inexplicables temores del infierno, concibiendo vivísimas representaciones de las penas que merecían sus pecados. Pero estas arideces no eran sólo experimentadas por Johanna de San Esteban; según De Certeau, la mística de los siglos diecisiete y dieciocho se da alrededor de una pérdida, una ausencia que multiplica las figuras del deseo. La entrada a la modernidad señala un fin y un principio (De Certeau, 1993: 24).

\section{La oración}

La vida espiritual tiene dos partes que se unen entre sí, como cuerpo y Alma, lo suave de la oracion con todos sus favores, regalos, ternuras, dulzuras, son como el Alma. Lo amargo de la mortificacion, y del desamparo, que incluie en si todas las penalidades, penitencias, tentaciones, y persecuciones de un espiritual son como el cuerpo, y como sola el Alma o solo el cuerpo, sino estan unidos entre sí, no constituyen al hombre: assi tambien sola la dulzura de la oracion, y la amargura de la mortificacion, sino se unen entre si, no hacen un varon espiritual, según las reglas de la mística (ACSC, Colección de la vida exemplar, fol. $48 \mathrm{v}$ ).

En la oración Johanna de San Esteban padeció durante mucho tiempo incomparables oscuridades, terribles aflicciones, temores espantosos y sequedades muy fogozas. Se le mitigaron por muchos años los consuelos divinos, ocultándosele Dios casi del todo, "pero como la esposa desolada con su amante escondido jamas desistio de solicitarlo en los caminos, desvelos de sus espirituales exercicios [...]". Su oración fue continua, su morada fue la casa de oración, pues vivía en el coro.

Para De Certeau las noches de los textos místicos "remiten a una situación general, pero también a modos de vivirla como problema existencial". Son relatos de "pasiones relativas a verdades que se escabullen, a autoridades cada vez más opacas, a instituciones divididas o enfermas". Las místicas definen no tanto conocimientos sino más bien un tratamiento distinto de la tradición cristiana. Acusadas con razón -reitera el autor-, de ser "novedades" sumisas y "ligadas" a las circunstancias, "pero fundadas en la fe en un Comienzo que debe ocurrir en el presente, las místicas establecen un "estilo" que se articula en prácticas que definen un modus loquendi [...]". La reinterpretación de la tradición posibilita un tratamiento diferente del lenguaje. "Son 


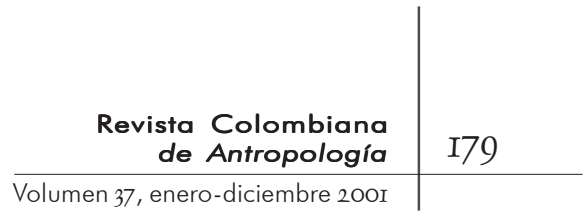

maneras de actuar que van organizando la invención de un cuerpo místico" (De Certeau, I993: 25).

El confesor de Johanna de San Esteban testimoniaba que pocos días antes de su muerte la veía en el coro, "atormentada de Ardientes calenturas, é intenssísimos dolores de modo que ya no podía sin notable trabajo moverse". Para consolarla la mandó no faltar al coro, pero otro día, al verla llena de angustia y en forma de cruz, postura en la que oró los últimos años de su vida, le dijo: "Señora el estar Usted en cruz ya no es virtud, sino manía”.

Fue devota del Ángel Custodio a quien le suplicó la defendiese de los asaltos del demonio. "[...] vido a su Santo Angel de la Guarda, [...] puesto a su lado [...] Armado de peto morreon y espada, mostrava estar aparejado y prompto para defenderla". Johanna de San Esteban lo hizo pintar así en una lámina que llevó consigo hasta que murió. A pesar de sus visones y de los favores de sus oraciones se lamentaba de no saber tener oración (ACSC, Colección de la vida exemplar, fol. 50v).

Fue gran conocedora de "libros espirituales y tratados de oración”. Frecuentemente hacía novenas, sobre todo a san José y oraciones vocales a la Virgen, pero sintiendo que no hallaba a Dios (fol. 5ir). Con la renta de sus alimentos fundó la capellanía de los sábados para la misa de Nuestra Señora, de quien también fue devota. De la oración frecuente sacaba la necesaria paciencia en sus trabajos. Su confesor decía que "siendo los dolores que padeció tan terribles y prolijos, jamás le oyó que se confesasse ni aun dudosa de que huviesse tenido, impaciencia”.

\section{El significado de la muerte de una religiosa}

F n la Última enfermedad se le agravó “la calentura”, de la

$\perp$ que padecía mucho. Reconociendo que le anunciaba ya la partida de esta vida a la eterna, se dispuso a recibir los santos sacramentos. Su confesor, Joan Baptista de Toro, afirmó que

notó en esta esposa de Jesuchristo, una mutación, tan admirable, como de la diestra del excelso, pues a la que oyo, vio y conocio, siempre tan temerosa de la muerte, no podía tolerar, la dilacion del morir, todas sus desconfianzas, y temores, se convirtieron, en seguras 
esperanzas, de que havía de lograr el ver a Dios; sus sequedades se volvieron incendios, de amores divinos. No enternecía poco, aun al corazon mas duro, de los que le acompañaron, en aquella ultima noche, oírle los gemidos, con que se lamentaba de la tardanza de la muerte (fol. 63v).

Compungidos, quienes la escuchaban lloraban a voz en cuello y decían a su confesor que no tardaría mucho y que el Señor quería dilatarle un poco el padecer, para que mereciera ir a gozarlo con brevedad (fol. 64r). Así pasó toda la noche. La última hora de su vida meditó la "sagrada pasión de Jesuchristo", leída por su confesor a petición de la monja. Tenía los ojos fijos en una imagen de Cristo crucificado y la Virgen de los Dolores, que siempre llevaba consigo. Repetía los coloquios y luego se callaba para escuchar. Después de pasar toda la mañana en continuos quejidos su confesor comenzó a leerle la Pasión, entonces enmudeció mirando la imagen (fol. 64v). Murió el 4 de octubre de 1708 a la una de la tarde, a los sesenta y seis años de edad (fol. 65v).

Poco después de conocer la noticia, "los ojos que havía en el convento" eran como "fuentes de lagrimas que corrían rapidamente, y assí se anegó, el monasterio en un mar de llanto; qual tendida en el suelo, se quedó casi sin habla, otras arrodilladas, estaban admiradas viendo el cuerpo desta Ve.[nerable] . Aquellas tendidas por los claustros dando tiernos sollosos" (fol. 65r).

Las religiosas, afligidas, se preguntaban quién las sacaría de sus dudas, quién consolaría sus espíritus afligidos, quién las socorrería en sus necesidades; otras, levantando las manos al cielo, pedían a su alma que rogara por ellas. Todo el monasterio era confusión, sin que unas a otras pudieran consolarse (fol. 65r). Sin tener que amortajar el cuerpo, porque murió vestida, la pusieron en el féretro y contrariamente a lo acostumbrado la llevaron al coro a las dos de la tarde. Allí "abrió los ojos mientras rezaron vísperas y completas”. Por esta novedad repicaron las campanas juzgando que había resucitado, pero cuando acabó el Oficio Divino, "no se volvieron a abrir” (fol. 65v). Al día siguiente llegó el Provisor a bajar el cuerpo al coro bajo, porque "eran muchas las suplicas del Publico, y personas de graduacion y respeto, que pedían ver a la Ve. Me., fue indesible el concurso, y las aclamaciones del Pueblo, pidiendo que tocasen en el cuerpo medallas Rosarios, y rogando a las religiosas, 


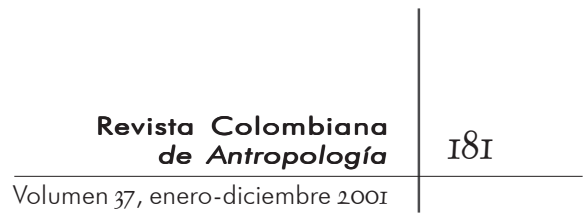

y al Señor Ordinario, para que les diesen de las flores que tenía esparcidas sobre el cuerpo" (fol. 66r).

A los quince días se dispusieron las honras a las que asistieron la real audiencia, los tribunales, el cabildo, comunidades y colegios, "ya porque esta señora era de padres senadores; e ilustre familia, ya por que assí lo merecía su perfeccion y santidad”. Ofició la misa el arzobispo Francisco Cosio y Otero acompañado del dean Carlos de Bernaola, predicó Fray Pedro Barroso, "hombre de conocida virtud y literatura" (fol. 66r).

Como corresponde a una persona de tanta santidad siguió manifestándose después de su muerte. El 26 de enero de I7IO la religiosa de velo blanco María de San Cristóbal, a quien Johanna de San Esteban socorría con limosna, necesitaba una saya; le pidió entonces que rogara a Dios para que moviera algún corazón que la ayudara; esa noche, una religiosa que nunca se había relacionado con ella le llevó el hábito. No sólo favoreció a las religiosas: a Isabel Forero la ayudó a mejorarse de la inflamación de un dedo de la mano al que durante un mes le había aplicado diferentes remedios; María Bernal, hallándose su vida en gravísimo peligro por un parto complicado, invocó su nombre y salió "enteramente buena"; Gertrudis, una criada del monasterio, sufrió un accidente mortal que le provocó un fuerte dolor en el estómago, fue asistida con una servilleta que había sido de Johanna de San Esteban "y sin otra diligencia se halló libre del achaque" (fol. 66v).

María de la Cruz contaba también que hallándose en ejercicios espirituales llegaron noticias de que Cartagena estaba amenazada por los ingleses, o "enemigos Herejes". Con este suceso se afligieron mucho las religiosas

temiendo, los desacatos y sacrilegios que podían venir, si ganavan los enemigos á Cartagena, y pasaban á esta ciudad; la Aprehension destos daños, las tenía perturbadas, y melancólicas,[...] saliendo de oración la V. Me. les dixo no se Aflixan que quien nos favorecio en Assís, nos amparará aquí. Y fue el caso que Johanna se durmió y en su sueño vió que abriendo el sagrario salía una Bandera Blanca, que llegaba hasta la tribuna, en la cual bandera, estaban escritas estas palabras, con letras de oro. No temais porque quien os defendio en Assís os defenderá aquí (fol. 57r).

Estas mismas palabras se las dijo a las religiosas, añadiéndo- 
les que los enemigos se habían retirado, viniendo luego noticias de que "los herejes, ya se havían ausentado y desistido de la empresa”. Esta es la única referencia a un acontecimiento del exterior en la biografía de Johanna de San Esteban, la cual demuestra su mínima relación con el mundo exterior. Este evento que la monja transformó en un hecho religioso revela el sentido que adquirían los hechos vistos desde la clausura, donde el tiempo se hilaba circularmente, y las estructuras antiguas y los acontecimientos medievales coexistían simultáneamente en el imaginario conventual y se utilizaban para dar una explicación religiosa y sobrenatural al curso de los acontecimientos. La principal función religiosa de las monjas de clausura ha sido orar desde su existencia mística por el mundo.

\section{Conclusiones}

A FORMA DE VIDA DE LAS CLARISAS SANTAFEREÑAS, QUE NACIÓ DE LA espiritualidad clariana del siglo trece, fue adaptada a la mo- dernidad por medio de las reformas tridentinas; por ello es posible encontrar la manifestación de dos grandes corrientes espirituales diferentes bajo el nombre de una misma orden.

Para llegar a ser monja clarisa se requería cumplir con una serie de requisitos. El primero de ellos, como ya se vio, estaba relacionado con la limpieza de sangre, que permitía el ingreso de la novicia. Después de un año de noviciado se hacía la profesión asumiendo los cuatro votos: obediencia, pobreza, castidad y clausura. El voto básico fue el de obediencia, porque sobre él se construyó la observancia de los demás. La pobreza fue concebida individualmente mas no en comunidad, contrariando así el espíritu original de la orden pero adaptando el convento a la modernidad, dentro de lo que De Certeau llamó la nueva formalidad de las prácticas destinadas por la contrarreforma a la ofensiva política. La castidad fue el voto que más atención recibió en los documentos consultados, por ser un aspecto que a la Iglesia de la contrarreforma le interesaba controlar estrictamente; al fin y al cabo, el desorden sexual de los jerarcas de la Iglesia medieval había sido uno de los principales blancos de las críticas luteranas. La castidad posibilitaba la pureza espiritual necesaria para que las religiosas pudieran acceder al matrimonio con Cristo y, a la 


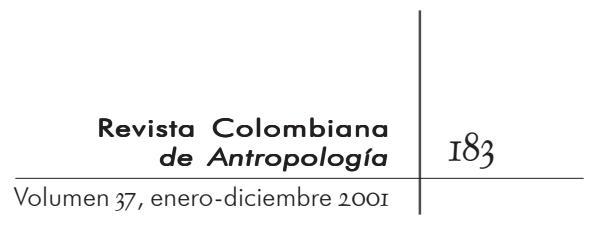

vez, confería a la Iglesia un poder económico enorme al configurarse como la única institución que podía recoger las herencias de las familias sin descendencia, o por lo menos la herencia de las religiosas que quisieran legarlas a la comunidad. La clausura permitió a los jerarcas eclesiásticos controlar el poder de la religiosidad femenina, y a las religiosas les marcó una forma de vida estrictamente normada por medio de una Regla cuyo objetivo principal fue institucionalizar el camino de la perfección individual, restando a la religiosidad femenina la posibilidad de ejercer su influencia directa en asuntos sociales y políticos.

Esta vida requería de un manejo específico del cuerpo y del comportamiento de las religiosas. Estructuraba su tiempo alrededor de la oración realizada a lo largo del día de acuerdo con el horario canónico, en el Oficio Divino. El tiempo era un medio para acceder a la perfección del espíritu y de la vida, un trayecto que las conducía a la muerte que significaba el encuentro final con el amado esposo y la consumación del desposorio místico. Por eso, al morir eran coronadas como novias. La forma como trataban su cuerpo es moderna, tiene que ver con la ambición de una radicalidad cristiana que, según De Certeau, se dibuja sobre un fondo de decadencia o de "corrupción" en el interior de un universo que se deshace y es necesario reparar. La mística repite en la experiencia biográfica todo el vocabulario de la reforma eclesial: la división, las heridas, la enfermedad, la mentira, la desolación. "Los cuerpos individuales narran la historia de las instituciones del sentido. El fin del mundo es postulado por todas las poéticas espirituales. Sus trayectorias luminosas y arriesgadas marcan con sus trazos una noche [...]”. Las visiones, el sufrimiento, las cadenas en el cuerpo, la forma de postrarse en la oración, el excesivo ayuno de religiosas como Jhoanna de San Esteban pueden considerarse lo que De Certeau llama un modus loquendi (modo de hablar).

Para la religiosa la muerte significaba la consumación del matrimonio místico y para la sociedad neogranadina era un acontecimiento religioso, político y social. Cuando la religiosa muerta era de limpia sangre y además poseía rasgos de santidad, las honras fúnebres eran un evento en el que participaban los diferentes poderes del reino. También, como en el caso de Johanna de San Esteban, se transforman en figuras ejemplares para las mujeres y en mitos para el pueblo que se congregaba a ver la santa muerta, a tocarla, a tomar un pétalo de las flores que cubrían su cadáver 
que convertiría en reliquia; un pedacito de santidad por medio del cual era posible acceder a milagros. La muerta es la actriz central del teatro barroco que la Iglesia postridentina se esmera en adornar. Nada como los cuerpos de los santos muertos para concentrar a los fieles alrededor de la "verdadera fe".

Puede afirmarse que el acceso al conocimiento establecido con la práctica de la vida religiosa femenina de la clausura, que alude a las formas en que las religiosas se apropiaron de las condiciones en que vivían, a sus experiencias y a sus modos de interpretación de lo normado, ha podido ser establecido mediante la lectura e interpretación crítica de los documentos conventuales citados, pero que, sin embargo, aun falta camino por recorrer, para entrar en un contacto más directo, no mediatizado, con estas protagonistas olvidadas y marginales de la historia neogranadina. Se tiene mayor conocimiento de lo normado que de lo vivido, y lo vivido de alguna u otra manera siempre llega al presente filtrado por diversidad de intereses. Sin embargo, la lectura entre líneas, los silencios o los excesos textuales, las metodologías cruzadas, son recursos que nos pueden permitir acceder a aquello que siempre será irrepetible: el aliento de lo vivido.

\section{Referencias DOCUMENTAles}

\section{Documentación inédita}

ACSC (Archivo privado del Convento Santa Clara), Bogotá. Colección de partituras. s.f.

_ Colección de la vida exemplar de la V Me Joanna Ma. De San Estevan religiosa del seraphico Monasterio d Sta. Clara desta ciudad de Stafe de Bogotá del Nuevo Rno. sacada a la luz por el presbítero Martín Palacios, quien la dedica al dueño de nras. Almas Jesús Sacramentado. I790.

Copia manuscrita de los registros y protocolos en los que consta la fundación original del Convento. Santafé, 7 de enero de 1792. s.f.

Diálogo entre un confesor y una religiosa profesa de la $2^{\mathrm{a}}$ Regla de su madre Sta. Clara dada por Urbano IV. Cuaderno manuscrito. s.f. 


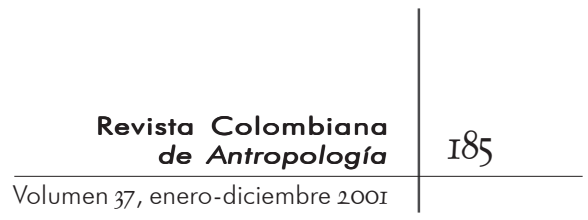

Colección de partituras. Cuarteto del maestro Herrera para la profesión de religiosas. 1702 .

AgN (Archivo General de la Nación), Bogotá. Conventos. Escritura de compraventa de una celda.

\section{BIBLIOGRAFÍA}

Anderson, Bonnie S. y Judith P. Zinsser. I99i. Historia de las mujeres: una historia propia. Serie Mayor. Crítica. Barcelona.

Benassy-Berling, Marie-Cecile. I983. Humanismo y religión en Sor Juana Inés de la Cruz. Universidad Nacional Autónoma de México. México.

Bravo, A. y L. Scaraffia. I979. "Ruolo femminile e identitá nelle contadine delle langhe un hipotesi di storia orale". En Rivista di storia contemporánea (I):27. Citado en Maurizio Ridolfi, "Lugares y formas de la vida cotidiana en la historiografía italiana". En La historia de la vida cotidiana, editado por Luis Castells, Ayer, no. 19. Marcial Pons Librero. Madrid. I995.

Campo Lacasa, Cristina. 1977. Historia de la iglesia en Puerto Rico. Instituto de Cultura Puertorriqueño. San Juan.

Caro Baroja, Julio. I995. Las formas complejas de la vida religiosa, siglos XVI y XVII. Galaxia Gutenberg-Círculo de Lectores. Barcelona.

Certeau, Michel De. 1993. La fábula mística, siglos XVI-XVII. Universidad Iberoamericana. México.

Foucault, Michel. 1985. Historia de la sexualidad. I. La voluntad de saber. Siglo XXI Editores. México.

Iriarte, LÁZARo, OMF. I98I. Escritos de san Francisco y santa Clara de Asís. Asís. Valencia.

1994. Letra y espíritu de la Regla de santa Clara. Asís. Valencia.

LAVRIN, AsUnCión. I993. "La vida femenina como experiencia religiosa: biografía y hagiografía en Hispanoamérica colonial”. En Colonial Latin American Review 2, (I-2).

comp. 1985. "Investigación sobre la mujer de la colonia en México, siglos XVII y XVIII". En Las mujeres latinoamericanas: perspectivas históricas. Fondo de Cultura Económica. México.

Loreto López, Rosalba. I995. "La sensibilidad y el cuerpo en el imaginario de las monjas poblanas del siglo XVII". En Memoria 
del II Congreso internacional El monacato femenino en el imperio español, monasterios, beaterios, recogimientos y colegios. Centro de Estudios de Historia de México. México.

LÜDTKE, Alf. I995. "De los héroes de la resistencia a los coautores: 'Alltagsgeschichte' en Alemania”. En La historia de la vida cotidiana, editado por Luis Castells. Ayer, $\mathrm{n}^{0}$ I9. Marcial Pons Librero. Madrid.

Madre de Dios, Agustín De LA. I984. Tesoro escondido en el santo carmelo mexicano: mina rica de ejemplos y virtudes en la historia de los Carmelitas descalzos de la provincia de la Nueva España, 374, 386-387. Universidad Iberoamericana. México. Citado en Asunción Lavrin, "La vida femenina como experiencia religiosa: biografía y hagiografía en Hispanoamérica colonial”, Colonial Latin American Review 2, (I-2) (1993): 30.

MARX, KarL. I852. "I8 Brumaire des Louis Bonaparte". Marx, EngelsWerke. Vol. 8: irs. Citado en Alf Lüdtke, "De los héroes de la resistencia a los coautores: 'Alltagsgeschichte' en Alemania”. En La historia de la vida cotidiana, editado por Luis Castells, Ayer, no. 19. Marcial Pons Librero. Madrid. I995.

Muriel, Josefina. 1992. Las mujeres de Hispanoamérica: época colonial. Mapfre. Madrid.

Paz, Octavio. 1998. Sor Juana Inés de la Cruz o las trampas de la fe.Seix Barrral. Barcelona.

Ramos Medina, Manuel. I99o. Imagen de santidad en un mundo profano. Universidad Iberoamericana. México.

Robledo, Ángela Inés (editora). I994. Autobiografía de una monja venerable: Jerónima de Java y Saavedra, I669-I727. Universidad del Valle. Cali.

Rubial García, Antonio. 1995. "Un caso raro: la vida y desgracias de sor Antonia de San Joseph, monja profesa en Jesús María”. En Memoria del II Congreso internacional El monacato femenino en el imperio español, monasterios, beaterios, recogimientos y colegios. Centro de Estudios de Historia de México. México.

Soeiro, Susan. 1985. "Las órdenes femeninas en Bahía, Brasil, durante la Colonia: implicaciones económicas, sociales y demográficas". En Las mujeres latinoamericanas: perspectivas históricas, I677-I800, compilado por Asunción Lavrin. Fondo de Cultura Económica. México.

Vances, Marcus De. I699. Regla, Constituciones y Ordenaciones de las Religiosas de S. Clara de la ciudad de S. Feê de Bogotâ en el nuevo Reyno de Granada de las Indias del Peru. Lucas Antonio Chracas. Roma. 